\title{
Effects of Technology Programes (three-dimensional models technique and multimedia) on Skillful Learning in Volleyball
}

\section{*Dr/ Abdallah Abdel Halim Mohamed}

\section{Introduction:}

The technology of education is at the forefront of science, which seeks to develop its content and concept from time to time, according to the changes of the modern era, which is characterized by the revolution of information and knowledge and technology in various fields, especially the scientific and educational field, which is developing on a daily basis. [50: 12]

In addition, education technology is concerned with the individual differences between learners. It provides the opportunity for individual learning according to the speed and ability of each learner, and to increase the efficiency and abilities of teachers, where their roles changes from teachers to mentors and organizers of diverse educational experiences, thus increasing the quality of the educational process for learners. To study, save time and effort, and make learning immediate. [32: 35]

The field of education technology has developed widely in the forms of media, communication and theoretical foundations of learning materials and systems. We have moved from silent films to programmed education, to multimedia packages, to web learning, etc. "Building" creativity can include a variety of activities based on the design model. Design and development processes are affected by a large number of digital and analog technologies used to build or configure learning materials and environments, Such as 3D interactive models \&designing a web-based constructivist learning environments and educational simulation systems. [24: 139]

Laurillard, Reiser et al. (2016) pointed out that one of the strengths of the definition of education technology is that

Department of Teaching Methods, Faculty of Physical Education, Sadat City University, Egypt Assiut Journal For Sport Science Arts 
it focuses on systematic processes and the use of technological resources and human performance technology. It also focuses on the analysis of education, performance problems, design, development, use, evaluation and management of educational and noneducational processes and resources, Institutions. The new concept of education technology has been linked to the field of teaching design and technology, such as threedimensional models, multimedia. [25: 3],[42: 10]

Multimedia is defined as a class of interactive communication systems that can be produced and delivered by the computer to store, transmit, and retrieve information contained within a written or audio network, music, graphics, stationary, video or animation, such as text, sounds, images, graphics and video. Collected or stored on a $\mathrm{CD}$ or on a computer network. Accordingly, Multimedia is content that uses a combination of different content forms such as text, audio, images, animations, video and interactive content. [23: 203],[37: 151]
Models is defined as technological means that can be used in the field of physical education. It helps in learning the skills of sports activities, simplifying the real things, and facilitating some parts. It also helps in identifying the internal parts and dealing with various problems such as spatial time and dimension. [54: 161]

Through the practical observation and supervision of practical education schools, the researcher noted that Overhead serve skill's performance level for the students in is characterized by randomness, poor performance and lack of coordination in motor sequence, and students cannot develop a correct perception of the skill in mind which leads to weak performance level.

Therefore, this study is an attempt to teach students with one of the most modern techniques in the field of volleyball teaching, by designing two programs using 3D interactive models and multimedia technology for study its effects on enhancing students skill`s performance level. Thus, studying the impact of an innovative educational technology (3D, 
multimedia) on volleyball motor skill`s learning.

\section{Objective}

The main aim of this study was designing two educational programs technological using 3D interactive models and multimedia technology and comparing their effects on skillful Learning in volleyball (the performance level of overhead serve skill) for preparatory stage pupils.

\section{Research hypothesis}

1. There are statistically significant differences between the pre-and post-measurements for first experimental group (three-dimensional models group) in the skill level of overhead serve in favor to the post measurement.

2. There are statistically significant differences between the pre-and post-measurements for second experimental group (multimedia group) in the skill level of overhead serve in favor to the post measurement.

3. There are statistically significant differences in post measurements between the two experimental groups (threedimensional models, multimedia) for the skill level of overhead serve in favor to the first experimental group (the interactive program group using the three-dimensional models).

\section{Methodology}

Method

The experimental
approach was used for two
experimental groups (3D
models, multimedia) using pre-
post measurements for each
group.

\section{Research sample}

The research society consisted of 152 students in the First graders in School of Abu Bakr Siddiq - City Sadat for the year 2016/2017. The basic sample was randomly selected from the students of the research society. The total number of the sample was (30) students with $24 \%$ of the total population. And (15) students by $12 \%$ of the total research community and outside the basic research sample as exploration sample to obtain scientific validity, and test the designed 3D models technique program and Multimedia program, and the sample was divided as follows:

- First experimental group: uses the designed threedimensional models technique in learning, (15) students.

- Second experimental group: uses multimedia program, (15) 
students.

\section{Tools}

1- Data recording forms (Appendix 1): Forms for recording the measurements and data for the sample: name, age, height, weight, intelligence score, fitness test scores, and the skillful test score skill for overhead serve were designed.

2- Tools and devices: Restameter device for measuring height and weight, distance tape measure, Bearings, medical balls, tennis balls, volleyballs, volleyball court.

3- Fitness elements tests (Appendix 2, 3): The fitness elements tests for the overhead serve skill were identified through the following scientific studies and references: (Ahmed 2013), (Zaki 2012), (Farid et al., 2012) ,(Mohamed, Hamdy 2005), (Physical tests 2016), (Ayat 2016), (Rehab 2013)

These references were used to identify:

- Fitness elements needed to perform the skill.

- Measurement tests for the fitness elements (physical tests).

The experts' opinion (Appendix 9) was reviewed. The experts pointed out that the fitness elements (accuracy, strength, capacity, coordination, and flexibility) Shown in Appendix (2).

The experts also pointed to the most appropriate tests for measuring these physical elements, which obtained an agreement rate higher than 75\%. (Appendix 9)

1. Overhead serve skill test (Appendix 4): Through the following scientific studies and references (Afaf et al., 2014), (Mohamed, Hamdy 2005), (Ayat 2016), (Rehab, Abdallah and Khaled 2013), The skillful test was determined to measure the level of performance of the overhead serve. In addition, the expert opinion (Appendix 9) was used to determine the tests to measure the skill, Experts agreed to the test of (Overhead serve accuracy for specific places) as shown in Appendix (4). 
Table (1)

Validity and stability of physical and skill tests $N=30$ (test validity), $N=15$ (test stability)

\begin{tabular}{|c|c|c|c|c|c|c|c|c|}
\hline \multirow{2}{*}{\multicolumn{2}{|c|}{ Variables }} & \multirow[t]{2}{*}{ unit } & \multicolumn{2}{|c|}{$\begin{array}{c}\text { Distinct } \\
15=N_{1}\end{array}$} & \multicolumn{2}{|c|}{$\begin{array}{c}\text { Non } \\
\text { distinct } \\
15=\mathrm{N}_{2}\end{array}$} & \multirow[t]{2}{*}{$\begin{array}{c}\text { Mean } \\
\text { differences }\end{array}$} & \multirow[t]{2}{*}{$\begin{array}{c}\text { T. } \\
\text { value }\end{array}$} \\
\hline & & & $\mathrm{M}$ & $\pm \mathrm{SD}$ & $\mathrm{M}$ & $\pm \mathrm{SD}$ & & \\
\hline \multicolumn{2}{|c|}{ Overhead serve test } & Degree & 12.95 & 1.55 & 9.14 & 2.45 & 3.81 & $* 8.62$ \\
\hline \multicolumn{2}{|l|}{ Accuracy } & Degree & 7.94 & 2.2 & 4.52 & 2.02 & 3.42 & $* 8.12$ \\
\hline \multicolumn{2}{|l|}{ Strength } & $\mathrm{Kg}$ & 19.88 & 2.65 & 16.2 & 2.7 & 3.68 & $* 8.45$ \\
\hline \multicolumn{2}{|l|}{ Capacity } & meter & 3.84 & 0.59 & 2.7 & 0.55 & 1.14 & $* 3.84$ \\
\hline \multicolumn{2}{|c|}{ Coordination } & Degree & 5.97 & 0.62 & 3.86 & 0.58 & 2.11 & $* 5.32$ \\
\hline \multirow{2}{*}{ Flexibility } & Frontal & $\mathrm{Cm}$ & 7.40 & 1.05 & 5.10 & 1.22 & 2.30 & $* 5.53$ \\
\hline & Background & $\mathrm{Cm}$ & 29.86 & 1.65 & 25.66 & 3.55 & 4.20 & $* 9.16$ \\
\hline \multirow{2}{*}{\multicolumn{2}{|c|}{ Variables }} & \multirow{2}{*}{ unit } & \multicolumn{2}{|c|}{$\mathbf{1}_{\text {st }}$} & \multicolumn{2}{|c|}{$\mathbf{2}_{\mathrm{n} . \mathrm{d}}$} & \multirow{2}{*}{\multicolumn{2}{|c|}{$\mathbf{C C}$}} \\
\hline & & & M & $\pm \mathrm{SD}$ & M & $\pm \mathrm{SD}$ & & \\
\hline \multicolumn{2}{|c|}{ Overhead serve test } & Degree & 9.14 & 2.45 & 9.20 & 2.55 & \multicolumn{2}{|l|}{$* 0.92$} \\
\hline \multicolumn{2}{|l|}{ Accuracy } & Degree & 4.52 & 2.02 & 4.55 & 1.20 & \multicolumn{2}{|l|}{$* 0.89$} \\
\hline \multicolumn{2}{|l|}{ Strength } & $\mathrm{Kg}$ & 16.20 & 2.70 & 16.26 & 2.72 & \multicolumn{2}{|l|}{$* 0.88$} \\
\hline \multicolumn{2}{|l|}{ Capacity } & meter & 2.70 & 0.55 & 2.71 & 0.45 & \multicolumn{2}{|l|}{$* 0.95$} \\
\hline \multicolumn{2}{|c|}{ Coordination } & Degree & 3.86 & 0.58 & 3.84 & 0.57 & \multicolumn{2}{|l|}{$* 0.95$} \\
\hline \multirow{2}{*}{ Flexibility } & Frontal & $\mathrm{Cm}$ & 5.10 & 1.22 & 5.08 & 1.20 & \multirow{2}{*}{\multicolumn{2}{|c|}{$\begin{array}{l}* 0.95 \\
* 0.92\end{array}$}} \\
\hline & Background & $\mathrm{Cm}$ & 25.66 & 3.55 & 25.63 & 3.52 & & \\
\hline
\end{tabular}

The value $(28,0.05)=2.05$, the t-value (cc) at a significant level (13, $0.05)=0.868$.

2- Kinovea-0.8.15 video analysis.

biomechanical analysis software: Video analysis software was used to analyze the performance and measure body segment's angles for the analysis sample.

3- $\quad$ DAZ Studio 4.9 (64-bit) software: to design the $3 \mathrm{D}$ educational models in accordance with the extracted data from the biomechanical

Technology programes (three-dimensional models technique and multimedia software):

\section{A. Program design of three- dimensional models}

The interactive program was designed using threedimensional models as shown below:

- The goal is to design an 
interactive program using three-dimensional models to know its effect on the performance level of the overhead serve skill in volleyball.

- The education content was analyzed through the curriculum (Ministry of Education 2011), In addition the following references that describing the skill (Farid et al., 2012),(Zaki 2012), (Mohamed, Hamdy 2005), (Tarek, Ayman 2006), (Ahmed 2007), (Ayat 2016), (Rehab, Abdallah and Khaled 2013), (Scientific Research 2016), which was used when designing the $3 \mathrm{D}$ interactive program.

- The technical performance of

Table (2)

the skill in question was analyzed according to the stages of technical performance shown in appendix according to the following stages:

A. Preparatory stage.

B. The main stage.

C. The final stage. (appendix

5). (Suzanne 2007),(Mohamed, Hamdy 2005), (Afaf et al., 2014),(Ayat 2016),(Rehab, Abdallah and Khaled 2013)

- The sample of the skill biomechanical analysis a correct performance trial of Overhead serve for "Francesca Piccinini" (appendix 6), and the following table shows the Characterization parameters of the motion analysis sample:

Characterization of the motion analysis sample

\begin{tabular}{c|c|c|c}
\hline \hline Age & Hight & Weight & Experience \\
\hline \hline$r q$ & $184 \mathrm{Cm}$ & $71 \mathrm{~K} . \mathrm{g}$ & 29 years \\
\hline \hline
\end{tabular}

Italian volleyball player Francesca Piccinini



(Francesca, May. July. August, 2016)

- Using the Kinovea-0.8.15 video analysis software to Assiut Journal For Sport Science Arts 
analyze the angles of the body parts during performance considering the following model of body parts consisting of (11) part representing the trunk, arms, and legs, as shown in Figure (1).

Figure (1)

\section{Body parts model used in skill motor analysis}

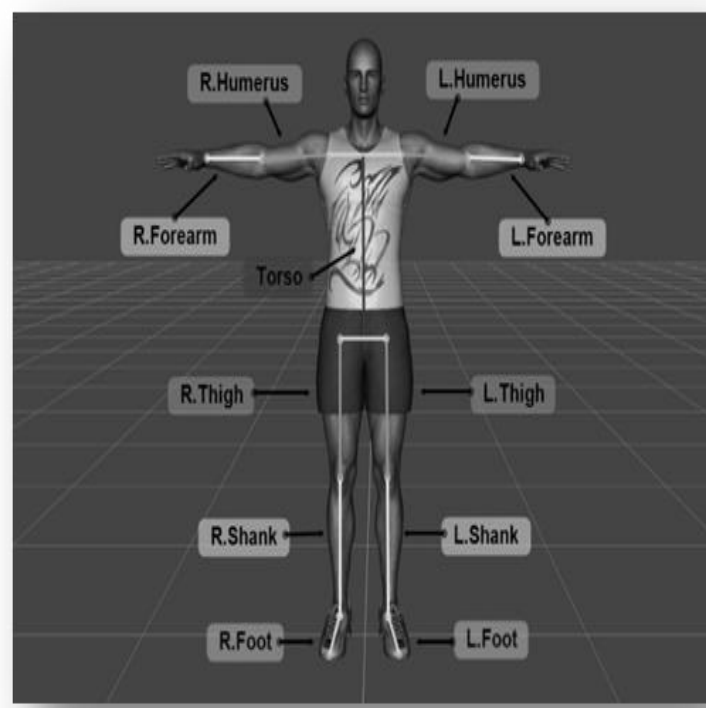

- 10 different frames representing were analyzed at different and successive stages of the above mentioned technical performance in appendix (5).

- The body parts angles were mainly based on the analysis for later use in the design of the skill 3D interactive models according to the steps and procedures of 3D model design suggested by (Talha 2016).

- The measurement of the body parts angles (as shown in Table 4) was from the positive horizontal axis $(+x)$, while the center of the coordinate system $(y, x)$ was positioned on the spindle of the part to be measured (z) as showed in figure (2). The measurements of the angles can be ascertained when used in the interactive modeling process. This method of measurement follows the principles of direct linear transformation theory, which gives constant measurements of angles regardless of distance, scale, or size. (Rasmussen et al., 2005). 
- Based on the (10) static models, the researcher designed additional (271) models to generate a complete dynamic 3D motion model of the overhead serve with the benefit of immersive interaction between learners and models.

- The skill technical points were demonstrated on the three-dimensional model using the Active presenter software as shown in appendix (7).

- The experts' opinion (appendix 9) of the 3D interactive program was reviewed and agreement was obtained on the validity of the interactive software for the skill 3D models and program.

- The proposed 3D interactive models were tested on a sample of the exploratory study to determine the suitability of the interactive program for the sample. This experiment resulted in the clarity of all the contents of the 3D modeling software among the sample students of the exploratory study.

B. Program design of multimedia

Multimedia program was designed as shown below:

Defining the aim of the program that suits its content
(Designing a multimedia program to know its effect on the performance level of the overhead serve skill in volleyball) for preparatory stage students.

The education content was analyzed through the curriculum (Ministry of Education 2011), In addition the following references that describing the skill (Farid et al., 2012), (Zaki 2012), (Mohamed, Hamdy 2005), (Tarek, Ayman 2006), (Ahmed 2007), (Ayat 2016), (Rehab, Abdallah and Khaled 2013),(Scientific Research 2016), which was used when designing the multimedia program.

The technical performance of the skill under research was described according to the following stages: Preparatory stage, The main stage, The final stage. (appendix 5) (Suzanne 2007), (Mohamed, Hamdy 2005) ,(Afaf et al., 2014), (Ayat 2016), (Rehab, Abdallah and Khaled 2013)

- The researcher prepared (8) learning units using Visual Basic language to have the opinion of experts about the appropriateness of these units. The experts 
approved the distribution of educational content (learning units) by $100 \%$ as shown in Table (7).

The importance of the program content of the sample was clarified, taking into account the grading factor in the design of the program.
Visual Basic software as shown in appendix (8). This point included the following:

* The program's main screen: Containing the introduction which clarifies the technological program idea for the skill under research using multimedia.

The skill display was organized under research using

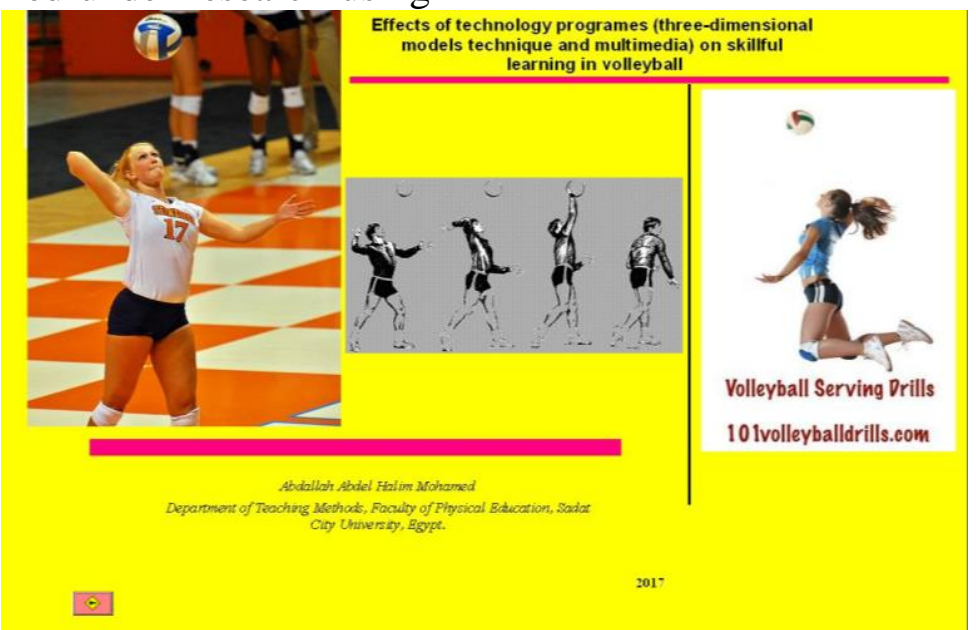

- The experts' opinion (appendix 9) of the program was reviewed and its appropriateness for the sample and agreement was obtained on the validity of a multimedia program for the skill under research.

- The proposed program was tested on a sample of the exploratory study to determine the suitability of the multimedia program for the sample. This experiment resulted in the clarity of all the contents of the multimedia software among the sample students of the exploratory study.

Moderation of sample distribution: 
Table (3)

Distribution moderation for basic and exploratory research sample $N=45$

\begin{tabular}{|c|c|c|c|c|c|c|c|}
\hline \multirow{2}{*}{\multicolumn{2}{|c|}{ Parameters }} & \multirow{2}{*}{ Unit } & & \multicolumn{4}{|c|}{ Statistical analyses } \\
\hline & & & \multicolumn{2}{|r|}{ Mean } & Median & SD & \multirow{2}{*}{$\frac{\mathbf{S K}}{\overline{1.32}}$} \\
\hline \multicolumn{2}{|l|}{ Age } & \multicolumn{2}{|c|}{ year } & 12.22 & 12 & 0.5 & \\
\hline \multicolumn{2}{|l|}{ Hight } & \multicolumn{2}{|c|}{$\mathrm{Cm}$} & 141.6 & 142 & 8.26 & -0.15 \\
\hline \multicolumn{2}{|l|}{ Wight } & \multicolumn{2}{|c|}{$\mathrm{Kg}$} & 40.3 & 40 & 6.28 & 0.14 \\
\hline \multicolumn{8}{|c|}{ Physical Tests: } \\
\hline \multicolumn{2}{|l|}{ Accuracy } & \multicolumn{2}{|c|}{ degree } & 4.51 & 4.55 & 2.01 & -0.06 \\
\hline \multicolumn{2}{|l|}{ Strength } & \multicolumn{2}{|c|}{$\mathrm{Kg}$} & 16.21 & 16 & 2.73 & 0.23 \\
\hline \multicolumn{2}{|l|}{ Capacity } & \multicolumn{2}{|c|}{ meter } & 2.73 & 3 & 0.51 & -1.59 \\
\hline \multicolumn{2}{|c|}{ Coordination } & \multicolumn{2}{|c|}{ degree } & 3.85 & 4 & 0.59 & -0.76 \\
\hline & \begin{tabular}{|l|} 
Frontal \\
\end{tabular} & $\mathrm{Cn}$ & & 5.17 & 5 & 1.24 & 0.41 \\
\hline Flexibility & Backgroun & $\mathrm{Cn}$ & & 25.65 & 26 & 3.54 & -0.3 \\
\hline Skillful T & st: & & & & & & \\
\hline Overhead & erve test & degr & & 9.17 & 9.00 & 2.50 & 0.20 \\
\hline $\begin{array}{r}\text { Samp } \\
\text { Equivale } \\
\end{array}$ & $\begin{array}{l}\text { le equivalen } \\
\text { nce of the two }\end{array}$ & $\begin{array}{r}\text { Pre- } \\
1 \\
\text { researc }\end{array}$ & $\begin{array}{l}\text { meas } \\
\text { able } \\
\text { h grot }\end{array}$ & $\begin{array}{l}\text { suremen } \\
(4) \\
\text { ups (tribs }\end{array}$ & $\begin{array}{l}\text { nt): } \\
\text { al me }\end{array}$ & ents) $\mathbf{N}$ & \\
\hline Parar & neters & $\begin{array}{r}\text { First exper } \\
\text { (3D mo } \\
15= \\
\end{array}$ & $\begin{array}{l}\text { imental } \\
\text { dels) } \\
\mathrm{v}\end{array}$ & $\begin{array}{r}\text { Sec } \\
\text { experi } \\
\text { (Multii } \\
15 \\
\end{array}$ & $\begin{array}{l}\text { cond } \\
\text { rimental } \\
\text { timedia) } \\
5=\mathrm{N}\end{array}$ & $\begin{array}{c}\text { Mean } \\
\text { Differences }\end{array}$ & $\mathbf{T}$ \\
\hline & & M & $\mathrm{SD} \pm$ & M & $\mathrm{SD} \pm$ & & \\
\hline Age & & 12.21 & 0.5 & 12.23 & 0.52 & 0.02 & 0.43 \\
\hline Hight & & 141.59 & 8.25 & \begin{tabular}{l|l}
5 & 141.61
\end{tabular} & \begin{tabular}{l|l}
1 & 8.26 \\
\end{tabular} & 0.02 & 0.45 \\
\hline Wight & & 40.32 & 6.3 & 40.31 & 6.29 & 0.01 & 0.39 \\
\hline & & Physica & Test: & & & & \\
\hline Accuracy & & 4.5 & 2 & 4.48 & 1.99 & 0.02 & 0.45 \\
\hline Strength & & 16.2 & 2.71 & 16.22 & 2.75 & 0.02 & 0.44 \\
\hline Capacity & & 2.72 & 0.5 & 2.75 & 0.55 & 0.03 & 0.5 \\
\hline Coordinatio & & 3.87 & 0.6 & 3.84 & 0.56 & 0.03 & 0.52 \\
\hline Elovihilitu & Frontal & 5.19 & 1.25 & 5.15 & 1.22 & 0.04 & 0.62 \\
\hline Fiexibility & Background & 25.69 & 3.6 & 25.64 & 3.59 & 0.05 & 0.66 \\
\hline
\end{tabular}

Skillful Test:

\begin{tabular}{|l||c|c|c|c|c|c|}
\hline Overhead serve test & 9.14 & 2.54 & 9.20 & 2.55 & 0.06 & 0.70 \\
\hline
\end{tabular}

T Table value at a significant level $(28,0.05)=2.05$ (two directions)

Assiut Journal For Sport Science Arts 
Application of the program:

The two program (3D models, multimedia) was implemented on the basic study sample (40 students) according to the time distribution, as shown in appendix (10) and the following table:

Table (5)

Time distribution of the program content for the two research groups

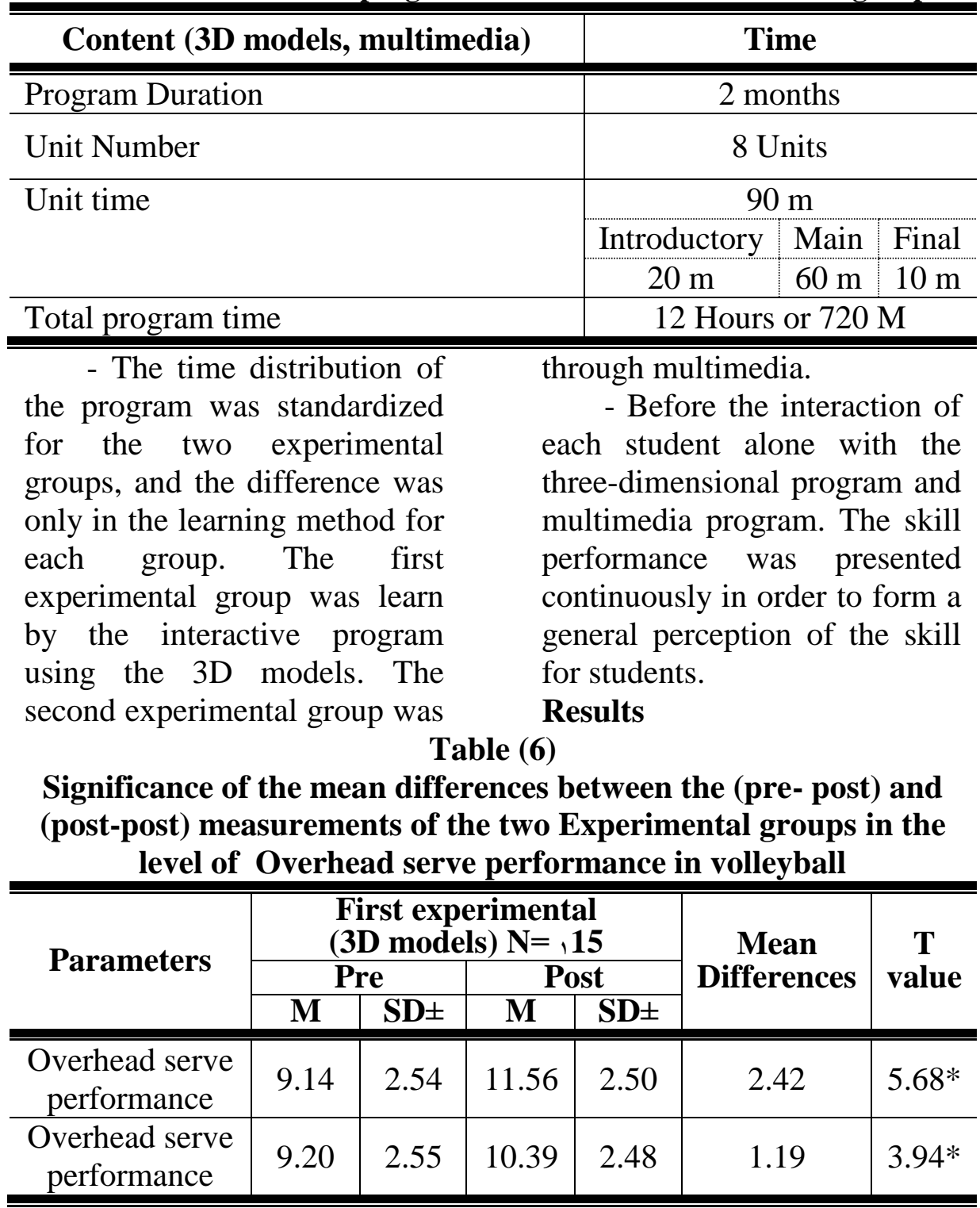


Follow Table (6)

Significance of the mean differences between the (pre- post) and (post-post) measurements of the two Experimental groups in the level of Overhead serve performance in volleyball

\begin{tabular}{|c|c|c|c|c|c|c|}
\hline \multirow{3}{*}{ Parameters } & \multicolumn{4}{|c|}{$\begin{array}{c}\text { Post measurement } \\
30=\mathrm{N}\end{array}$} & \multirow{3}{*}{$\begin{array}{c}\text { Mean } \\
\text { Differences }\end{array}$} & \multirow{3}{*}{$\begin{array}{c}\mathbf{T} \\
\text { value }\end{array}$} \\
\hline & \multicolumn{2}{|c|}{$\begin{array}{c}\text { First } \\
\text { experimental }\end{array}$} & \multicolumn{2}{|c|}{$\begin{array}{c}\text { Second } \\
\text { experimental }\end{array}$} & & \\
\hline & $\mathrm{M}$ & $\mathrm{SD} \pm$ & $\mathrm{M}$ & $\mathrm{SD} \pm$ & & \\
\hline $\begin{array}{l}\text { Overhead serve } \\
\text { performance }\end{array}$ & 11.56 & 2.50 & 10.39 & 2.48 & 1.17 & $3.88 *$ \\
\hline
\end{tabular}

T Table value at a significant level $(14,0.05)=1.76$.

$\mathrm{T}$ Table value at a significant level $(28,0.05)=1.70$.

\section{Discussion}

First research hypotheses: (3D models)

The results of Table (8) show that there are statistically significant differences between pre and post mean values of the first experimental group (3D models) where the value of calculated (t) (5.68) is greater than the value of table $(\mathrm{t})$ at a significant level (0.05), which indicates the higher level of skill performance for the post measurement.

The researcher attributed the reason for these differences to the experimental variable only, which is represented in the three-dimensional interactive models. The researcher also attributes the progress made to relying on the complete clarity of the interactive models by explaining the angles of body parts in the skill performance in each model of the program, In addition to clarifying the performance of the skill through the active presenter and thus the higher level of skillful performance for the first experimental group (interactive models).

Thus, the first hypothesis is achieved, which stated that there are statistically significant differences between the pre-and post-measurements for first experimental group (the interactive program group using the 3D models) in the skill level of overhead serve in favor to the post measurement. Second research hypotheses: (Multimedia) 
The results of Table (8) show that there are statistically significant differences between pre and post mean values of the second experimental group where the value of calculated (t) (3.94) is greater than the value of table (t) at a significant level (0.05), which indicates the higher level of skill performance for the post measurement to the second experimental group (the interactive program group using multimedia).

The researcher attributes the level of progress and improvement in these results to the experimental variable only, which is the use of the multimedia method in the learning of the skill in question. This indicates that the presentation of learning in the multimedia method has a positive effect on the skill and knowledge of the skill performance content through multimedia and information that helps to form a clear picture by text, sound and image of this skill (Overhead serve skill).

This indicates that learning in the form of multimedia has a positive effect on the skill performance of students. Which is consistent with the study of "Ayat, Eman" (2016), "Rehab et al. "(2013), "Medina" (2016), “Tarek, Ayman" (2006), “Ahmed" (2007), "Ayat"(2009), "Jean, Luyt" (2015), "Smorzewska" (2015), These studies indicated that the computer groups based on the use of multimedia method have a positive effect on the technical variables under consideration.

Therefore, the second hypothesis is achieved, which stated that there are statistically significant differences between the pre-and post-measurements of the interactive program group using multimedia in the skill level of overhead serve in favor to the post measurement.

Third

research

\section{hypotheses:}

The results of Table (8) show that there are statistically significant differences in post mean values between the two experimental groups where the value of calculated (t) (3.88) is greater than the value of table $(\mathrm{t})$ at a significant level (0.05), which indicates the higher level of skill performance for the first experimental group (interactive models group) than the second experimental group (multimedia group). 
This indicates that the progress in the skill level of the first experimental group compared to the second group is due to the reliance on the $3 \mathrm{D}$ interactive program and the diversity of models, images, sound, and video, thus the positive impact on the level of performance of the skill due to the attractiveness and effectiveness of the threedimensional models.

The researcher also explained the reason for the difference between the two experimental groups by including the interactive program using the threedimensional models of the important technical points that were explained on the threedimensional model using Active presenter software as described and shown in appendix (7).

Therefore, the third hypothesis is achieved, which stated that there are statistically significant differences between the two experimental groups in post measurements for the skill level of overhead serve in favor to the first experimental group (three-dimensional models).

\section{Conclusion}

- The multimedia program has a positive effect on the skillful learning under research in volleyball.

- The interactive program using the three-dimensional models have a positive effect on the skillful learning under research in volleyball.

- The three-dimensional models led to a higher level of skillful performance compared to the multimedia.

\section{Recommendations}

- Encouraging the use of 3D models program for middle school students because of its effect in raising the level of skillful performance.

- Introducing programs designed through interactive models in the curricula of the middle schools (the preparatory schools).

\section{References}

1- Afaf Mohamed Khattaby, Elham Abdel-Moneim Ahmed, Dalia Mohamed Hashim: Applications in Volleyball, Helwan university press, Faculty of physical education, Helwan university 2014.

2- Ahmed Rady Elawaty: "A training program for the development of traffic forecasting components and its impact on the performance level of some defense skills for volleyball

players" 
Unpublished Master thesis, Faculty of Physical Education in Fleming, Alexandria University 2013.

3- Ahmed Talaat Abu-Zeid: "The impact of educational program using multimedia on cognitive achievement and the level of basic skills in volleyball for middle school students" Unpublished Master thesis, Faculty of Physical Education, Mansoura University 2007.

4- Ahmed Zaki Saleh: Educational Psychology, Edition 14, Library of AlNahda Egyptian, Cairo 2008.

5Anderson, T.,

\& Shattuck, J.: Design-Based Research: A Decade of Progress in Education Research? Educational Researcher, 41(Jan/Feb.), 1625. Retrieved from http://edr. sagepub.com/content/41/1/7.ful 1.pdf+html, 2012.

6- Asma Nageh Omar: "An electronic program to develop the technical performance of the long jump player" Unpublished Master thesis Faculty of Physical Education Bani Sweif University 2016.

7- Asma Shaltout: "The effect of interactive threedimensional models on teaching the long jump"
Unpublished Master thesis Faculty of Physical Education Sadat University 2016.

\section{8- Ayat Abdel-Halim}

Mohamed Aly: Learning by technological modeling and its effect on the performance level of Overhead Serve skill in volleyball, Scientific Journal of Sports Sciences \& Arts. (Publications; search number 110 , part 2, June 2020, ISSN 1110-8460-2020-102) at www.ijssa-gezira.com. Faculty of P.E for girls, University of Helwan, 27 June 2016.

9- Ayat Abdel Halim Mohamed Aly: "The Effect of an educational program on the level of skillful and knowledge of Spike in volleyball", Unpublished Master thesis, Faculty of Physical Education Gezera, Helwan University 2009.

10- Ayat Abdel-Halim Mohamed Aly, Eman AbdelHalim Mohamed Aly: The effect of different Teaching Styles on Learning some Volleyball Skills for Female P.E Students (Comparative Study). The international scientific Journal of Physical Education and Sport, Sciences, NSSN 24003, Print issn: 2356/9565, Online issn: 2356/9573, Volume (3), 98- 
106, Faculty of Physical Education, Helwan University, January 2016.

11- Drmosad: Methods, techniques in Physical Education, at http://www.drmosad.com/inde x101.htm, pp. 3, 6 May 2016.

\section{2- Eman Abdel-Halim}

Mohamed: "Program design using multimedia and its impact on the outcomes of practical teaching methods learning course for students of the Faculty of Physical Education" unpublished doctoral thesis - Faculty of Physical Education Gezera Helwan University 2014.

\section{3- Eman Abdel-Halim} Mohamed, Ayman Mordy Abdel-Bari: "Interactive program using three dimensional (3D) models and its effect on the skillful performance in volleyball for female preparatory pupils in P.E lesson" Scientific Journal "Sports Sciences Applications" (Publications, Volume; Issue 99, March 2019, ISSN 23570032), Faculty of Physical Education - Abu Qir, Alexandria university, 11 April 2016.

\section{4- Essam El-Din Metwally} Abdallah: Methods of teaching physical education between theory and practice the world of sports publishing and Dar Al-Wafa for printing, pp. 37, Alexandria 2016.

15- Facer, K. \& Sandford, R.: The next 25 years?: Future scenarios and future directions for education and technology . Journal of Computer Assisted Learning, 26, 74 - 93 . doi: 10.1111/j.

1365-2729.2009.00337.x

[Crossref], [Web of Science ®], [Google Scholar], 2010.

\section{6- Farid Abdel-Fattah} Khashaba, Hossam Khalifa, Mahmoud Metwally:

Fundamentals of volleyball between theory and application, Rashid Press، second edition, Cairo, Arab Republic of Egypt. pp 45, 2012.

17- Francesca Piccinini: Volleyball, Italian volleyball player Francesca Piccinini, at https://ar.wikipedia.org/wiki/\% D9\%81\%D8\%B1\%D8\%A7\% D9\%86\%D8\%B3\%D9\%8A\% D8\%B3\%D9\%83\%D8\%A7 \% D8\%A8\%D9\%8A\%D8\%AA\% D8\%B4\%D9\%8A\%D9\%86\% D9\%8A\%D9\%86\%D9\%8A\#/ media/File:Francesca_Piccinin 3.jpg, 18 July 2016.

18- Francesca Piccinini: Volleyball, Italian volleyball player Francesca Piccinini, at 
https://commons.wikimedia.or g/wiki/File:Francesca_Piccinin i_3.jpg, 17 May 2016.

19- Francesca Piccinini: Volleyball, kooora, at http://www.kooora.com/?playe $\mathrm{r}=83050,20$ August 2016.

20- Hassan Rebhi Mahdi: Book of Educational Technology and Learning, Dar Al-Masirah, pp. 17, Jordan, 2015.

21- Hayword T.: Advemtures In Virtual Reality Compased In chetten Ham And Mpc Digital by Prentice Hall Computer, Publishing by Our Carparation, Modison, Wisconsim, Dubuque, Lower. 2003.

22- Jean Chastre, CharlesEdouard Luyt: Factors affecting the e-learning outcomes, Telematics and Informatics, Volume 32, Issue 4 , November 2015, Pages 701719, 2015.

23- Jethro, O. Grace, A. M., \& Thomas, A. K.: E-learning and its effect on teaching and learning in a global age. International Journal of Academic Research in Business And Social Sciences, 2(1), 203-210, 2012. 24- Jin, L., Wen, Z. , \& Gough, N.: Social virtual worlds for technology enhanced learning on an augmented learning platform . Learning, Media and Technology, 35 (2), 139 153 . doi: $10.1080 / 17439884.2$ 010.494424, [Taylor \& Francis Online], [Web of Science ®], [Google Scholar], 2010.

25- Laurillard, D.: Rethinking university teaching: A conversational framework for the effective use of learning technologies ( 3 nd ed.). London : Routledge Falmer, [Crossref], [Google Scholar], pp. 3, 2016.

26- Medina John: Active Education, Growing Evidence on Physical Activity and Academic Performance, at http://www.supportrealteacher org/articles-on-physicaleducation-physical-activity-academic-achievement.html, Physical Educator, 64(3), 2016. 27- Ministry of Education: Teacher's Guide in Physical Education - Modern Printing House - Cairo 2011.

28- Mohamed Attia Khamis: Theoretical and Historical Assets of E-Learning Technology, Edition 2, Dar AlSahab for Printing, Publishing and Distribution, pp. 41, Cairo, Egypt, 2016.

\section{9- Mohamed Ismail}

Ibrahim: "The effectiveness of learning using the method of 
modeling supported by cartoon graphics on the development of some elements of fitness physical education lesson for students of the first cycle of basic education in the city of Minya", Journal of Sports Science, Vol I, December 2013.

30- Mohamed, S.H., \& Hamdy, A.: The scientific bases of volleyball and measurement methods for evaluating (physically. Skill. Cognitive. Psychological. Analytical), book centre for publishing, second edition, Cairo. Arab Republic of Egypt. pp 34, 2005.

31- Mohamed, S.Z., \& Moustafa M.S.: Technology development and rehabilitation of physical education teacher. Dar El-wafaa for Publishing, second edition, Alexandria, Arab Republic of Egypt. pp 190-191, 2004.

\section{2- Moustafa Al-Sayeh}

Mohamed: The Technological Approach, Learning and Information technology in Physical Education, Dar Al Wafa, pp. 35,36, Alexandria 2004.

\section{3- Moustafa Mohamed} Abdel-Sameea: Educational Technology, Arab Studies,
Book Center $2^{\text {nd }}$, pp. 53, Cairo 2009.

34- Moustafa, M.S.: Teaching methods in physical education. Technical radiation library for publishing, second edition, Cairo. Arab Republic of Egypt. pp 166, 2003.

35- Osman Abdullah: "The impact of a program using super images supported by the model of learning dimensions on some elements of fitness and trends for first cycle of basic education students", Journal of Sports Science, Vol II, Minia, December 2013.

36- Physical tests: volley ballegypt, Physical tests in volleyball, at http://www.volleyballegypt.co $\mathrm{m} / \mathrm{vb} /$ showthread.php? $\mathrm{p}=1335$ , 24 June 2016.

37- Piotr Leszczyński, Anna Charuta, Beata Laziuk, Robert

Arkadiusz

Magdalena Gałązkowski, Barbara Kołodziejczak: Multimedia and interactivity in distance learning of resuscitation guidelines: a randomised controlled trial. Interactive Learning Environments journal, ISSN: 1049-4820 Online ISSN: 1744-5191, Pages: 151- 
162, Published online: 14 Jun 2016.

38- Rasmussen J, de Zee M, Damsgaard M, Christensen ST, Marek C, Siebertz K.: A general method for scaling musculo-skeletal models. 2005 International Symposium on Computer Simulation in Biomechanics; Cleveland, $\mathrm{OH}$, US, 2005.

\section{9- Rehab Adel Gabal:} "Designing an educational program using the international information network and its impact on the implementation on the physical education lesson aspects in the light of the overall quality standards", Journal of Science and Sports Arts - Volume 39 - Faculty of Physical Education, Gezera, Helwan University, June 2011.

40- Rehab Adel Gabal, Abdallah A. Mohamed and Khaled A. El-Battawy: "Effects of Teaching Strategy (cooperative learning and computer) on Learning the volleyball skills in P.E. Lesson", Journal of Physical Culture and Sport, Studies and Research, 24th of October 2013, Warsaw, Poland.

41- Rehab Adel Gebal, Duaa Hosny El-Shalakany: "The Effect of an Educational Program Using the Computer on Learning Some Basic Skills in Volleyball for Middle School Girls in the Physical Education lessons", Journal of Applications of Sports Science , Issue 91, Faculty of Physical Education in Abu Qir, Alexandria University, 2016.

42- Reiser, Woo Y.\& Reeves, TC.: Meaningful interaction in web-based learning: A social constructivist approach . Internet and Higher Education , $10,15-25$. doi: $10.1016 / \mathrm{j}$ iheduc.2006.10.005, 2016.

\section{3- Scientific Research:}

Faculty of Physical Education, Assiut University, at http://www.aun.edu.eg/faculty_ physical_education/arabic/rese arches.php?Dept_Code=1001, 2 April 2016.

44- Smorzewska E.: Selected Examples of Interactive Teaching Methods in the Centre of Geoeducation in the City of Kielce (Poland). Social and Behavioral Sciences, Volume 173, Pages 214-220, 2015.

45- Suzanne Badran Sulaiman: Volleyball, Menoufia university press, Faculty of physical education Sadat university 2007.

46- Talha, A. Hossam El Din: Applicability of interactive Assiut Journal For Sport Science Arts 
educational 3D models in teaching sports and motor skills, International Journal of Sports science and Arts.2016, ISSN 2356-9417-0013 E, 2016. 47- Talha, A. Hossam El Din: The Biomechanical Parameters For Designing Motor Skill's 3D Educational Models, The international scientific Journal of physical education and sport sciences. Special issue, 2016. 48- Talha, A. Hossam El Din: "Using E-learning in learning the subject of teaching methods" Unpublished Master thesis, Faculty of Physical Education, Sadat university 2011.

49- Talha, A. Hossam El Din, Abdallah A. Mohamed and Rehab Adel Gabal: "Emerging technological applications and their use in the educational process", Scientific Journal of Physical Education and Sports, Faculty of Physical Education, Helwan University 2015.

\section{0- Tamer El-Mallah:} Education Technology: The New Concept and its Elements, Faculty of Education, Egypt, at https://www.new-educ.com/, pp. 12,36, 10 November 2016.

51- Tarek Mohamed AbdelAziz, Ayman Abdo

Mohamed: "The impact of educational program using computer on the level of skill and cognitive achievement in volleyball for students of Physical Education Faculty, Assiut University", Assiut Journal of Sport Sciences and Arts, Volume 4, Assiut University, 2006.

52- Wescott, Bob: The Every Computer Performance Book, Chapter 7: Modeling Computer Performance. CreateSpace.ISB N 1482657759, 2013.

53- Wikipedia: 3D modeling, The free encyclopedia, at https://ar.wikipedia.org/wiki/\% D9\%86\%D9\%85\%D8\%B0\%D 8\%AC\%D8\%A9_\%D8\%AB\% D9\%84\%D8\%A7\%D8\%AB\% D9\%8A\%D8\%A9_\%D8\%A7 $\% \mathrm{D} 9 \% 84 \% \mathrm{D} 8 \% \mathrm{~A} 3 \% \mathrm{D} 8 \% \mathrm{~A} 8$ $\% \mathrm{D} 8 \% \mathrm{~B} 9 \% \mathrm{D} 8 \% \mathrm{~A} 7 \% \mathrm{D} 8 \% \mathrm{AF}$, 22 March 2016.

54- Zaghloul, Mohamed Saad., Makarem Helmy AbuHarja and Hani Said AbdelMoneim: Educational Technology and Methods in Physical Education, Book center, $2^{\text {nd }}-$ p.161, Cairo 2001. 55- Zaki, M.H.: Teaching volleyball methods. Technical radiation library for publishing, Cairo. Arab Republic of Egypt, pp 40, 2012.

\section{Assiut Journal For Sport Science Arts}

